\title{
Gallbladder Cancer pT1 TNM Finding v8
}

National Cancer Institute

\section{Source}

National Cancer Institute. Gallbladder Cancer pT1 TNM Finding v8. NCI Thesaurus. Code C134647.

Gallbladder cancer with tumor invading the lamina propria or muscular layer. (from AJCC 8th Ed.) 